\title{
Criminal Responsibility and Challenges in the Criminal Justice System for People with Intellectual Disability in Norway
}

\author{
ERIK SØNDENAA, CHRISTINE FRIESTAD, BIRGITTE \\ STORVIK, AND BERIT JOHNSEN*
}

\section{Introduction}

The purpose of this article is to present and discuss Norwegian legislation concerning intellectual disability and criminal responsibility. We will describe the current state of the Norwegian legislation, present a historical overview based on changes in the last century, and discuss the implications for different stages in the criminal justice process. Current legislation has an internationally uncommon feature, in that the rules governing criminal responsibility are based on what is known as the medical principle. This principle entails that criminal responsibility is determined by the defendant's mental health status at the time of the crime. Unlike most other jurisdictions, Norwegian criminal law does not require any causal or correlational relationship between the mental condition and the crime.

* $\quad$ Erik Søndenaa, Norwegian University of Science and Technology, Institute of mental health; St. Olavs University Hospital, Centre for Research and Education in Forensic Psychiatry.

Christine Friestad, Oslo University Hospital, Centre for Research and Education in Forensic Psychiatry; University College of Norwegian Correctional Service.

Birgitte Storvik and Berit Johnsen, University College of Norwegian Correctional Service.

This work was supported by the Norwegian Directorate for Children, Youth, and Family Affairs.

This is an Open-access article distributed under the terms of the Creative Commons Attribution 3.0 Unported License (http://creativecommons.org/licenses/ by/3.0/), permitting all use, distribution, and reproduction in any medium, provided the original work is properly cited. 


\section{Intellectual Disability and Criminal Responsbility}

\subsection{Current Legal Regulations}

According to section 20 of the Norwegian Penal Code, persons above the age of 15 who commit crimes and are found to be mentally retarded to a high degree (psykisk utviklingshemmet $i$ høy grad) are not criminally responsible and cannot be punished. ${ }^{1}$ In the Norwegian legal literature, the concept of punishment has traditionally been defined as the infliction of an evil that is supposed to be experienced as an evil, ${ }^{2}$ or, in Christie's words: to inflict pain. ${ }^{3}$ It is an uncommon feature of Norwegian criminal law that the mere existence of serious mental retardation is sufficient to avoid criminal responsibility. The law sets no demand for causality or correlation between a lack of mental capacity and the crime. This is the so-called medical principle in Norwegian penal law, which differs from most other countries. ${ }^{4}$

The legal term 'mental retardation to a high degree' is not defined in the Penal Code but has been elaborated through relevant legal sources ${ }^{5}$ and covers persons with an intellectual functioning level corresponding to an IQ of below 55. Because of the risk of inaccurate test results, it is explicitly stated that the IQ limit be considered indicative and not absolute. The personality of the offender and his or her level of social functioning are other important factors to consider when diagnosing mental retardation. ${ }^{6}$ However, legal sources do not provide more precise guidance than this, and the legal delineation of mental retardation may therefore be difficult and inaccurate. In criminal cases it is for the courts to make the final decision, based on advice from court-appointed forensic experts. It has been debated in Norway whether the courts are too willing to accept the views of forensic experts, and whether the determination of criminal responsibility in such cases is a medical decision or an independent legal decision. ${ }^{7}$

Much is at stake for the offender, as a conclusion of 'mental retardation to a high degree' entails a lack of criminal responsibility. Persons who are found to be mentally retarded to a high degree are absolved from criminal responsibility and punishment.

LOV-2005-05-20-28 om straff (Penal Code), section 20 first paragraph, letter c.

See Andenæs, Alminnelig strafferett, 5th ed. (Universitetsforlaget 2004).

See Christie, Pinens begrensning (Universitetsforlaget 1981).

4 See Syse, Strafferettslig (u)tilregnelighet - juridiske, moralske og faglige dilemmaer, Tidsskrift for Strafferett 3 (2006), pp. 141-175.

5 See NOU 1990: 5, Strafferettslige utilregnelighetsregler og særreaksjoner, Straffelovkommisjonens delutredning IV (Norwegian Public Reports 1990: 5 on criminal insanity rules and special sanctions), p. 42.

6 See World Health Organization (2000) ICD-10.

See Boucht, Om strafferettslig utilregnelighet i norsk rett - med noen synspunkter fra et nordisk perspektiv, Lov og Rett 9 (2012), pp. 515-532. 
As the main rule, they should therefore be fully acquitted, but can under certain conditions be sentenced to so-called mandatory care (tvungen omsorg), a special type of sentence of indeterminate duration. Norway's Penal Code sets stringent criteria for bringing people with intellectual disabilities (ID) into the scope of mandatory care. ${ }^{8}$ These include the commission of a serious and life-threatening crime by a person defined as non-responsible due to ID, with an intellectual functioning corresponding to moderate or more severe ID (IQ<55). The risk of reoffending must also be regarded as high before a sentence to mandatory care can be imposed.

The use this sentence depends on the severity of the crime committed and the assessed risk of reoffending. If the crime is of a kind that poses a serious threat to other people's lives, health or freedom-such as serious violence (including sexual violence) or arson-and the court finds a sufficiently high risk of re-offending, the court will pass a sentence of mandatory care in order to protect society. Less serious crimes of the same character can also be grounds for a special sentence in cases where the offender has committed the same kind of crime previously and a close connection between the former and current crime can be established. Crimes that have been harmful or particularly distressing to society can also result in mandatory care, but here again a risk of the individual committing further offences of the same type must be evident and other measures must be clearly proven to be unsuitable. ${ }^{9}$ Sentences of mandatory care are brought to an end through an order from the court or the prosecution authorities when the risk of reoffending is no longer considered real or qualified (see section 65 of the Penal Code). While in mandatory care, the person is under the responsibility of the specialist health services.

Persons with ID who commit crimes and do not meet the criteria of being mentally retarded to a high degree-i.e., those who have an IQ of over 55-are viewed as criminally responsible and are thus given a regular sentence, to be served either in prison or in society (e.g., community service). Where the person has a mild ID, defined as having an IQ of 55-75-which is considered mentally disabled to a lesser degree according to Penal Code sections $78(\mathrm{~d})$ and $80(\mathrm{~g})$ - there is the possibility for the court to reduce the sentence. The evaluation of the proper reduction of the sentence is open for certain judicial discretion, but there is no possibility for the court to absolve the person fully from punishment. Norwegian scholars have criticised this lack of a discretionary basis for absolving an offender with ID from punishment, pointing to the risk of unreasonable results in cases where ID offenders with an IQ of just over 55 are given regular, only slightly reduced, prison sentences. ${ }^{10}$ According to the results of a national review, however, these rules in sections 78 and 80 have been almost unused in recent years. ${ }^{11}$

$8 \quad$ Penal Code section 63, see also section 62.

$9 \quad$ Ibid.

10 See Hennum, Tilregnelighet, Materialisten 4 (2008), pp. 5-27.

11 See Mæland, Sagfossen and Revis, Etterkontroll av reglene om strafferettslig utilregnelighet, strafferettslige scerreaksjoner og forvaring (Justis- og politidepartementet 2008). 
If criminally responsible persons with ID (i.e., those found not to be mentally retarded to a high degree) commit crimes of a serious nature, they can be sentenced to preventive detention (forvaring). The same criterion is used for a sentence of preventive detention as for one of mandatory care (Penal Code section 40), except that crimes which are harmful to society or of a particularly distressing nature will result in an ordinary sentence. A sentence of preventive detention, as with one of mandatory care, is time-unlimited, and the court may extend the sentence as long as the risk of committing new and serious crimes is considered high. When passing a sentence of preventive detention, the court must set a time frame and a minimum term (Penal Code section 43). A person sentenced to preventive detention cannot be held in prison beyond the time frame given without a new sentence extending it (Penal Code section 43 , first paragraph). The minimum term regulates when the person can apply for parole (Penal Code section 44, first paragraph). The maximum time frame the court may set is 21 years ( 30 years for acts of severe terrorism), and the maximum minimum term is 10 years, or 14 years if the time frame is set to more than 15 years (maximum 20 years for acts of severe terrorism).

\subsection{The Historical Scope: Care and Custody Throughout the Last Century}

The current Norwegian forensic legislation and system concerning people with ID ${ }^{12}$ came into effect in 2002. Before January 2002, convicted persons with ID were sentenced to preventive supervision in the municipality where they lived. People with severe ID were considered mentally ill in the legal sense and therefore unfit to be legally punished. People with both severe or less severe ID could be sentenced to preventive supervision, either as a substitute for prison or in addition to it. Convicted criminals with mild ID who were sentenced to prison but were mentally unfit to serve their sentence also had their penalty converted to the same kind of preventive supervision. ${ }^{13}$ When deinstitutionalisation was effected in Norway in 1991 and all institutions closed down, there was a significant increase in the number of persons sentenced to preventive supervision up until 2002. ${ }^{14}$ Forced to respond to this increase, the authorities initiated a special arrangement with full financial support for the settlement and care of these persons in the community. This arrangement has since been strengthened in the new arrangement of mandatory care (discussed later).

The criminal justice system also required alternatives for offenders with ID. This

12 Based upon recommendations in NOU 1990: 5.

13 See Nøttestad and Linaker, People with intellectual disabilities sentenced to preventive supervision - mandatory care outside jails and institutions, Journal of Policy and Practice in intellectual Disabilities 2(3-4) (2005), pp. 221-228.

14 See Johnsen, Prøveløslatelse fra forvaring med vilkår om opphold i institusjon eller kommunal boenhet utover ettårsfristen - ikke bare noen, men mange problemstillinger, Kritisk Juss 38(1) (2012), pp. 29-51. 
was because of a need, amongst other things, to separate offenders with ID from other offenders with mental disorders, and to give them appropriate care. ${ }^{15}$ This led to legislative reform, which in 2002 instituted a new legislative definition of criminal responsibility, a new special sanction for ID offenders, and a national unit responsible for managing all persons sentenced to mandatory care based on serious intellectual disability.

In the first decades of the $20^{\text {th }}$ century, Danish people with ID were separated into two groups: those with intellectual disabilities and those with 'moral disabilities. ${ }^{16}$ Both groups were treated separately in forensic mental healthcare. According to Norwegian historian Svein Atle Skålevåg, the Norwegian approach was based on a different explanation of ID. The main difference was that in Norway, ID was not classified separately but considered to be part of a spectrum of mental disorder. Skålevåg $(2003)^{17}$ argues that different perspectives and professional positions on ID during the first decades of the $20^{\text {th }}$ century may reflect major differences in diagnostic traditions between these Nordic countries. As a consequence, ID services were subordinated to mental health services in Norway, in contrast with several other countries.

Through the $20^{\text {th }}$ century, research based on investigations of forensic reports/examinations indicated the presence of a significant proportion of offenders with ID in the Norwegian criminal justice system (CJS) ${ }^{18}$ A replication of this study confirmed that at least $10 \%$ of all forensically examined alleged offenders had an ID with an IQ of below $75 .{ }^{19}$

During the last 30 years, most Western countries have seen a trend towards deinstitutionalisation, including institutions for people with ID. This process has been faster and more complete in Norway and Sweden than in other countries. ${ }^{20}$ All the institutions for people with ID have been closed and people with ID are now living in community settings. ${ }^{21}$ The specified need for care and treatment for people with ID in Norway is regulated in social service legislation. Services are provided by the municipality, which has responsibility for both the security and welfare of people with ID.

15 See Hennum, Nye strafferettslige særreaksjoner, Materialisten 30(1/2) (2002), pp. 24-42.

16 See Kirkebæk, Da de åndssvage blev farlige (SocPol 1993).

17 See Skålvåg, Fra normalitetens historie. Sinnssykdom 1870-1920, PhD thesis (University of Bergen 2003), pp. 317-318.

18 See Dalgard, Abnorme Lovovertredere. Diagnose og Prognose (Universitetsforlaget 1966).

19 See Noreik and Grunfeld, Mentally retarded persons who have undergone psychiatric forensic examination, Tidsskr Nor Laegeforen 118(14) (1988), pp. 2149-2151.

20 See Beadle-Brown, Mansell and Kozma, Deinstitutionalization in intellectual disabilities, Curr. Opin. Psychiatry 20(5) (2007), pp. 437-442.

$21 \quad$ Norway closed all its institutions for people with ID in 1991, and municipal authorities were called upon to establish locally based services and accommodation. No institutions were left in the country to serve offenders or other people with a need for specialised services because of concomitant ID. 
The effects of deinstitutionalisation in Norway did not appear to have much impact on the frequency and nature of behavioural disturbances and psychiatric disorders among people with ID, ${ }^{22}$ causing a need for legal regulation of the use of coercive measures in order to prevent self-harm or harm to others. Hence, a special act regulating the application of restraint measures in caring for people with ID was introduced into Norwegian social service legislation in $1999 .{ }^{23}$ These regulations, and consequently these options in Norwegian services for people with ID, appear to be used to prevent some people from offending. ${ }^{24}$ However, the number of defendants with ID is probably dependent on the knowledge and attitudes of the caregiver as to the line between challenging behaviour and criminal acts. The civil act on coercive measures can be used to prevent harm, and some criminal offences could possibly have been avoided by use of the coercive civil options.

\section{Competence and Accountability}

The legal management of offenders with ID is characterised by a high degree of inconsistency between and within countries. ${ }^{25}$ Many approaches are formally prescribed by statute; others have evolved through judicial decisions. ${ }^{26}$ The questions of whether a person is 'competent to stand trial' or 'fit to plead' are determined based on such factors as: 1) the ability to understand the nature and potential consequences of the charges brought against oneself; 2) a general understanding of the workings of the court; and 3) an ability to work co-operatively with one's lawyer/partake in one's defence. ${ }^{27}$ Although the threshold for being fit or unfit differs between nations, there

22 See Nøttestad, Deinstitutionalization and mental health changes among people with mental retardation (NTNU 2004).

23 See LOV-1991-12-13-81 om sosiale tjenester m.v. (Act on Social Services etc.) chapter 4A (1991). The regulations on coercive treatment for people with ID were replaced in 2012 by LOV-201106-24-30 om kommunale helse- og omsorgstjenester m.m. (Act on Municipal Public Health Services etc.) chapter 9; and Røed and Syse, Physical intervention and aversive techniques in relation to people with learning disabilities in Norway, J. Adult Protection 4(1) (2002), pp. 25-32.

24 See letter from the Ministry of Health and Care Services to the County Governor of Oslo and Akershus, Complaint case regarding the social services law chapter $4 \mathrm{~A}$ - Restraint in the care of people with intellectual disabilities who offend - the interpretation of the law ('Klagesak etter sosialtjenesteloven kapittel 4A - bruk av tvang og makt overfor enkelte personer med psykisk utviklingshemning som begår straffbare handlinger - forespørsel om lovforståelse'), dated 21st of October 2009.

25 Søndenaa, Rasmussen and Nøttestad, Forensic issues in intellectual disabilities, Current Opinion in Psychiatry 21 (2008), pp. 449-453.

26 See Brookbanks and Freckelton, Legal issues concerning offenders with intellectual and developmental disabilities, in Offenders with intellectual and developmental disabilities: research, training and practice, eds. Lindsay and Taylor (Wiley 2018).

27 See Mikkelsen, The assessment of individuals with developmental disabilities who commit criminal offenses, in Offenders with developmental disabilities, eds. Lindsay and Sturmey (Wiley 2004). 
are standards and suggestions exemplified by the Competence Assessment for Standing Trial for Defendants with Mental Retardation (CAST-MR). ${ }^{28}$ This is a structured interview consisting of 50 questions covering the three abovementioned areas of competency.

\section{Custody and Care of Intellectually Disabled Offenders}

\subsection{The Practical Arrangements}

In Norway, mandatory care is managed by a national unit (see Penal Code section 64). It is separated from other mental health units and serves only persons with ID who have committed crimes. Intellectually disabled persons serving a sentence of mandatory care are first placed in this national unit. Later on, they are transferred to local health services that are upgraded in order to be able to cater for the needs of each individual. The national unit remains responsible for both public safety and the rehabilitation of the offender throughout the entire period of the sentence. An important incentive for the local health services to admit someone sentenced to mandatory care in the community, and to adapt their services to that person's needs, is that all expenses while the person serves their sentence are covered by the state. As the person will most likely be transferred to the community once the mandatory care is ended, most local health services consider this a good opportunity to establish adequate services for the person that can continue beyond the time of the mandatory care sentence.

Persons receiving a sentence of imprisonment who are identified as being mentally disabled to a lesser degree, or have an ID that is not recognised, serve their sentence in ordinary prisons and prison units. This means that there are no units especially adapted for persons with ID within the Correctional Service. In accordance with the principle in the Norwegian Correctional Service of serving a sentence as close to home as possible, ${ }^{29}$ imprisoned people with ID serve their sentences in prisons all over the country. A distinguishing feature of the Norwegian prison system is the high number of smaller prisons (fewer than 50 prisoners). Being held in a small prison may be positive for a person with ID, as there are fewer people to relate to and the structure of the prison is not as complex as it is in larger units (e.g., fewer levels in a hierarchical organisation). However, small prisons may lack the competence to handle and take care of persons with ID. On the other hand, it may be more difficult for a person with an unidentified ID to hide their disability, as they are more visible to staff.

28 See Everington and Luckasson, Competence assessment for standing trial for defendants with mental retardation (CAST-MR), (1992).

29 Meld. St. 12 (2014-15), see also St. meld nr. 37 (2007-2008) 


\subsection{Preventive detention}

Preventive detention should commence in prisons or units adapted for prisoners with special needs. ${ }^{30}$ In these types of prisons, the wings hold between five and eleven prisoners, the area for social interaction between prisoners and staff is quite spacious, and staff should have received different kinds of training allowing them to work across disciplines to meet prisoners' needs. ${ }^{31}$ Such facilities should therefore be more capable of meeting the needs of people with an ID sentenced to preventive detention. In order to reduce the risk of committing new offences, a person sentenced to preventive detention should, within sound bounds of safety and security, be given the opportunity to change his/her behaviour and adapt to a life of liberty. ${ }^{32}$ These regulations also presuppose more extended and individually designed programmes for prisoners serving sentences of preventive detention than for prisoners serving ordinary prison sentences. ${ }^{33}$ The Correctional Service is obliged to design individual programmes where the needs and prospects of persons with ID are taken into consideration, and to prepare them for gradual adaptation to a life of liberty. ${ }^{34}$

\section{Challenges for ID Offenders Inside the Criminal Justice System}

Over the last two or three decades, international studies of offenders with intellectual disabilities inside the CJS have demonstrated the need for services for this minority group, which tends both to be neglected in the CJS and to reoffend more frequently. Historically, only those ID defendants whose cognitive impairments were most obvious were identified by the courts. Typically, these offenders were committed to the more appropriate services for people with ID. ${ }^{35}$ The misplacement of offenders with ID in the mental health system (inappropriate facilities) and those in the correctional system (inappropriate programmes) has been described elsewhere ${ }^{36}$ and still feels relevant after 50 years. A common dilemma is that people with ID who have offended, or are at risk of offending, may be dismissed by mainstream ID services as being too difficult to treat. They may also be rejected by local ID services, either because

See LOV-2001-05-18-21 om gjennomføring av straff m.v. (Act on the execution of sentences etc.) section 11 third paragraph and section 10 second paragraph. See also FOR-2004-03-05-481 om gjennomføring av særreaksjonen forvaring (Regulations on the implementation of preventive detention) section 6 first paragraph.

$31 \quad$ NOU 1990: 5, p. 111.

32 Regulations on the implementation of preventive detention, section 2.

$33 \quad$ Idem, section 6.

$34 \quad$ Idem, section 3.

35 See Brown and Courtless, The mentally retarded offender, in Readings in law and psychiatry, eds. Allen, Ferster and Rubin (Johns Hopkins Press 1968), pp. 364-390. Ibid. 
they are not considered to be in need of services or because they are considered too great a risk to other people in the service system. ${ }^{37}$ Internationally, there appears to be a variety of approaches in cases of offenders with ID. Research presents several options both within and diverted from the CJS. ${ }^{38}$ This is also the situation in Norway, where sanctions may take into consideration the vulnerability of a person in a prison environment and lead to alternative arrangements that are more conducive to community-based care. This has been implemented in some cases during the last year, but for now most offenders with ID still end up in regular prisons.

The majority of ID offenders in Norway, as in other countries, have a mild or borderline ID. These people are considered to be criminally responsible and, according to recent data and research, most had not been identified as having ID or been offered special arrangements within the criminal justice system. Since almost all persons who are sentenced to preventive detention have been subjected to forensic examination, ${ }^{39}$ there are good reasons to believe that persons with ID in this group are identified. A significant proportion of prisoners without a recognised ID fall into a criminal justice trap: they are socially and personally vulnerable, but have no ID identification, no facilitation, and no proper aftercare. A prevalence study of ID in Norwegian prisons was conducted in $2008 .{ }^{40} \mathrm{~A}$ total of 143 randomly selected prisoners were interviewed and tested for IQ and suggestibility. The study reported $10.8 \%$ as having an IQ of below 70 (ranging from 56-69) and numerous disadvantages associated with their intellectual problems. Compared with non-ID prisoners, these offenders appeared to have had significant adaptive problems since childhood, a higher rate of mental health problems as adults, more convictions, and hence had spent more time in prison. Those prisoners with the lowest level of competence were, paradoxically, excluded from CJS rehabilitation and educational programmes. None of the ID prisoners had been identified by any parts of the CJS as being intellectually disabled, probably due to a lack of knowledge in this area on the part of the relevant professionals (lawyers, police officers and prison officers). The basic lack of knowledge in all parts of the criminal justice system in Norway makes the vulnerability of people with ID even worse. Where it is not known that a person has ID, the CJS will not take into account the needs and difficulties that are specific to people with intellectual problems. Several studies have stressed that the majority of persons with ID experience considerable injustice at various stages in the CJS, beyond that experi-

37 See Hayes, Pathways for offenders with intellectual disabilities, in Offenders with developmental disabilities, eds. Lindsay, Taylor and Sturmey (Wiley 2004); Holland, Clare and Mukhopadhyay, Prevalence of criminal offending by men and women with intellectual disability and the characteristics of offenders implication for research and service development, J. Intellect. Disabil. Res. 46 (2002), pp. 6-20.

$38 \quad$ Ibid.

39 See Johnsen, Elleve år med forvaring: Løslatelser - praksis og rettspraksis - og tilbakefall, Lov og Rett 52(6) (2013), pp. 385-405.

40 See Søndenaa et al., The prevalence and nature of intellectual disability in Norwegian prisons, $J$. Intellect. Disabil. Res. 52 (2008), pp. 1129-1137. 
enced by other groups of offenders. ${ }^{41}$ The possible consequences of having an ID may render sufferers vulnerable to victimisation through all phases of the CJS.

\subsection{Arrest and conviction}

During their initial contact with the CJS, alleged offenders with ID are exposed to several situations with a potential source of bias or conflict. During interrogation, suspects with cognitive impairments tend to be more suggestible and therefore more vulnerable to the pressures of interrogation. ${ }^{42}$ The lack of knowledge among CJS staff about the presence of ID means that they often do not request a pre-trial forensic examination, and the strain throughout the trial prevents offenders with ID from appealing the conviction..$^{43}$ In Norway there is the option of sentencing offenders to a community sentence as an alternative to prison (Penal Code section 48). The main purpose of a community sentence is to prevent dropout from the labour market ${ }^{44}$, and it has been used increasingly frequently since it was established in 2002 . However, the statistics do not include any details on offenders with ID. ${ }^{45}$

\subsection{Imprisonment and post release}

Research on Norwegian prison inmates with ID has revealed that more than $10 \%$ have IQ scores of below 70. These prisoners were found to be disadvantaged compared with other inmates in several respects: they were less educated; they had more past and present mental health problems; they were not included in prison rehabilitation programmes; they had had more imprisonments; and they had spent on av-

41 See Clare and Gudjonnson, The vulnerability of suspects with intellectual disabilities during police interviews: a review and experimental study of decision making, Mental Handicap Research 8 (1995), pp. 110-128. Everington and Dunn, A second validation study of the Competence Assessment for Standing Trial for Defendants with Mental Retardation (CAST-MR), Crim. Justice Behav. 22 (1995), pp. 44-59. Fulero and Everington, Assessing competency to waive Miranda rights in defendants with mental retardation, Law and Human Behavior 19 (1995), pp. 533-543. Gardner, Graeber and Machkovitz, Treatment of offenders with mental retardation, in Treatment of offenders with mental disorders, ed. Wettstein (Guilford Press 1998), pp. 329-364. Petersilia, Unequal Justice? Offenders with mental retardation in prison, Correctional management quarterly 1(4) (1997), pp. 36-43.

42 See Newsletter 19 from the Forensic Committee Psychiatric unit (Den rettsmedisinske kommisjon, nyhetsbrev nr. 19 fra psykiatrisk gruppe), June 2008, and Olsen et al., Rettssikkerhet - Likeverd og likeverdig behandling (Nordland Research Institute report 5/2018).

43 See Søndenaa et al. (2008).

44 See Skardhamar, Straffegjennomføring med samfunnsstraff $i$ Norge (SSB-report 13/2013).

45 See Statistics Norway, Straffereaksjoner, etter type reaksjon og lovbruddskategori. 1997- 2017. Absolutte tall og per 1000 innbyggere uploaded 03.05.2019. From https://www.ssb.no/statbank/ table/10622/ (Last accessed $9^{\text {th }}$ September 2019). 
erage almost three times as long in prison. ${ }^{46}$ Prison staff expressed doubts about the adequacy of the resources allocated to inmates with ID. ${ }^{47}$ They pointed out several problems, including the lack of identification of people with ID, their lack of appropriate support, exclusion from prison rehabilitation services, less access to prison information, poor insight into their own offending circumstances, victimisation in prison, and a lack of supporting strategies among prison staff. ${ }^{48}$ Prisoner rehabilitation programmes are generally not adjusted to support the needs of people with ID, and when these prisoners do not take part in rehabilitation programmes, this in turn results in fewer signs of improvement. ${ }^{49}$ Their lack of pro-social or problem-solving skills, which often contribute to their coming into contact with the CJS in the first place, is usually unchanged upon their release.

With regard to preventive detention, the Correctional Service is obliged to adapt rehabilitative programmes in accordance with prisoners' needs. ${ }^{50}$ This means that where the ID is known, the Correctional Service has to take the prisoner's intellectual capacity into consideration and adapt rehabilitative measures accordingly.Moreover, when offenders are released there is usually no distinction made between ID and non-ID parolees, and there are no local agencies appointed to serve people with ID. Having a criminal record, the ID offender may have problems getting a job and will experience social isolation, a lack of community support, homelessness and an unstructured life, increasing the risk of criminal recidivism. In contrast, persons sentenced to preventive detention have a special arrangement whereby they may be released on parole by the court with the condition that they live in a residence where there are staff to ensure that society is protected from new and serious crimes. The staff is also involved in rehabilitative measures, such as milieu therapy, and in various activities both inside and outside the residence. Several persons with ID have been released into this kind of parole arrangement. According to Penal Code section 44, a person may be placed under this arrangement for up to five years; however, the problem is that persons with ID stay in these residences beyond that limit, some for more than 15 years. The reason for these long-lasting stays is that these people have fairly severe levels of ID (but not an IQ $<55$ ) and limited potential for rehabilitation. The risk of recidivism and moving onto new, serious crimes (such as sexual offences) is unlikely to be reduced, thus preventing them from being released.

46 See Søndenaa et al. (2008).

47 Talbot, No one Knows: Identifying and supporting prisoners with learning disabilities and learning difficulties: the views of prison staff, Prison Reform Trust report, London.

48 Søndenaa et al. (2008).

49 See Gardner, Graeber and Machkovitz, Treatment of offenders with mental retardation, in Treatment of offenders with mental disorders, ed. Wettstein (Guilford Press 1998), pp. 329364. Hayes, Missing out: offenders with learning disabilities and the criminal justice system, Br. J. Learn. Disabil. 35(3) (2007), pp. 146-153. Petersilia, Justice for all? Offenders with mental retardation and the California corrections system, The Prison Journal 77(4) (1997), pp. 358-380. Regulations on the implementation of preventive detention section 3. 
Statistics and a few reports from the forensic psychiatric services have, since the 1950 s, found a significant prevalence of offenders with ID $^{51}$-in between $8-10$ and 30 percent of forensic psychiatric examinations.

\section{Status and Future Perspectives}

The system of mandatory care for ID offenders with 'mental retardation to a high degree' was introduced into Norwegian legislation in 2002, reducing the number of ID offenders who were exempted from regular criminal sanctions. ${ }^{52}$ Norwegian rules are very conservative compared with the criminal legislation of most other European jurisdictions, resulting in a minority of ID offenders being diverted from the mainstream CJS. Recent data confirm a small proportion of sentences of mandatory care. Between 2002 and 2018, only 23 persons were sentenced, of whom 11 are still serving their sentence. The national unit, Brøset, has also served as an alternative to being remanded in custody, with 19 such remands since 2002, of which five were subsequently sentenced to mandatory care.

Although just a small group, ID offenders have special needs that the normal forensic system (including prisons) seems unable to meet. The purpose of the Norwegian model is to meet their needs for care as well as society's need for protection. The benefit of providing community services directed at offenders with ID is internationally supported. ${ }^{53}$ In one study, it was found that compared with more restrictive, forensic hospitals, services in the community reduced risk, were more cost-effective, and provided high-quality community support. ${ }^{54}$

The absence of proper identification, care and treatment of offenders with ID who do not meet the criteria for forensic ID services has been documented in recent research. In recent years, several weak points of the current forensic mental health system have been debated and some changes initiated. For example, interrogation methods have been revised, in collaboration with the Norwegian Association for Persons with Developmental Disabilities. However, these initiatives appear to be di-

51 See Dalgard, Abnorme Lovovertredere. Diagnose og Prognose (Universitetsforlaget 1966). See also Newsletter 19 from the Forensic Committee Psychiatric unit (Den rettsmedisinske kommisjon, nyhetsbrev nr. 19 fra psykiatrisk gruppe), June, and Noreik and Grünfeld, Mentally retarded persons who have undergone psychiatric forensic examination, Tidsskr Nor Laegeforen 118(14) (1998), pp. 2149-2151.

52 See Søndenaa, Linaker and Nøttestad, Effects of the changes in legislation governing offenders with intellectual disabilities in Norway: a descriptive study, J. Policy Pract. Intellect. Disabil. 6 (2009), pp. 229-235.

53 See Barron, Hassiotis and Banes, Offenders with intellectual disability: a prospective comparative study, J. Intellect. Disabil. Res. 48 (2004), pp. 69-76.

54 See Benton and Roy, The first three years of a community forensic service for people with a learning disability, Br. J. Forensic Practice 10 (2008), pp. 4-12. 
rected foremost at a limited group of offenders with ID, i.e., those already known to the social ID services. A crucial point for future success rests on responding to McBrien's warnings fifteen years ago: 'One of the most prevalent vulnerable groups amongst offenders comprises those who do not have an intellectual disability as formally defined but who do have much lower cognitive and adaptive abilities than do either the general population or the offending population. ${ }^{55}$

\section{Consideration, Discussion, Future Perspectives}

A suggestion to the Norwegian parliament (Prop. 154L (2017)) has argued that the inclusion criteria for the term 'mentally retarded to a high degree' should change from IQ $<55$ to IQ $<60$. Such a change would increase the number of people considered non-accountable due to intellectual disability; based on normal distribution, it would lead to a threefold increase in the proportion of the population falling under this definition ( $0.135 \%$ with an IQ below 55 and $0.379 \%$ with an IQ below 60$)$. It is, however, difficult to foresee the consequences of such a change for criminal justice services. Since the legal changes in 2002, 18 persons with a 'mental retardation to a high degree' have been sentenced to mandatory care, while a further five have had their original sentence converted to one of mandatory care. In last year's parliamentary debate, expanding the criteria for serious intellectual disability was supported by research showing that many offenders with ID are incarcerated as regular prison inmates. ${ }^{56}$ On the other hand, questions have been raised about the possible financial consequences of increasing the number of offenders who will need very expensive care arrangements. ${ }^{57}$ The care and treatment of offenders with ID is highly specialised, but comparisons with services operating in other countries reveal several alternatives. Great Britain and Denmark have institutionalised forensic services for convicted persons with ID, and alternative models to the costly decentralised Norwegian model could be considered if the criteria of being sentenced to mandatory care becomes less restrictive.

55 See McBrien, The Intellectually disabled offender: methodological problems in identification, $J$. Appl. Res. Intellect. Disabil. 16(2) (2003), pp. 95-105.

$56 \quad$ See Søndenaa et al. (2008).

57 See Rosenqvist et al., Helsehjelp som straffereaksjon (article in Morgenbladet newspaper, 12 January 2018). 